\title{
The Eolianites between Sanga do Cabral and Botucatu Formations in Rio Grande do Sul State, Brazil*
}

\author{
CARLOS H. NOWATZKI and HENRIQUE P. KERN \\ NESE, UNISINOS, Cx. Postal 275 - 93001-970 São Leopoldo, RS, Brazil \\ Manuscript received on October 21, 1998; accepted for publication on November 29, 1999; \\ presented by Diogenes de Almeida Campos
}

\begin{abstract}
This paper discusses the facies distribution of Mesozoic eolian sandstones between the Sanga do Cabral and Botucatu formations and also their contact relationships, in São Leopoldo area, State of Rio Grande do Sul (RS), southern Brazil. The main distinctive characteristics regarding these sandstones and formations are the mineralogical composition, paleocurrents and the occurrence of wet interdune deposits. These interdune deposits are characterized by frequent thin mudstone layers with mudcracks, ichnofossils and salt impressions. There are also some features that resemble plant fossils. The distinctive characteristics of these sequences to Sanga do Cabral and Botucatu formations allow us to suggest the informal name of Pedreira Sandstone, considering its type section, the Pedreira Cliff, at Sapucaia do Sul, RS.
\end{abstract}

Key words: stratigraphy, Paraná Basin, Mesozoic, faciology, paleoenvironments.

\section{INTRODUCTION}

In São Leopoldo area, State of Rio Grande do Sul (Figure 1), between deposits of Sanga do Cabral (Late Permian - Early Triassic) and Botucatu (Jurassic - Cretaceous) formations, eolian sandstones with distinctive characteristics from the eolianites of those units are found.

White (1908) was the first to study the area's stratigraphy; however, only in the 60's the geological observations were systematized

${ }^{*}$ To Rodi A. Medeiros, in memoriam Correspondence to: Carlos Henrique Nowatzki

E-mail: nowa@euler.unisinos.tche.br
(Morris 1963, Fensterseifer 1979, Andreis et al. 1984, Zeltzer et al. 1992, Faccini \& Nowatzki 1993, Nowatzki 1997).

Geological sections made along federal, state and municipal roads made it possible to analyze more than the facies distribution (lithology, geometry of the beds, sedimentary structures, paleocurrents and fossils), the contact relationships between the existing units, making whenever possible, details of profiles in representative outcrops. A simplified geological map of São Leopoldo area was made based upon these data. 


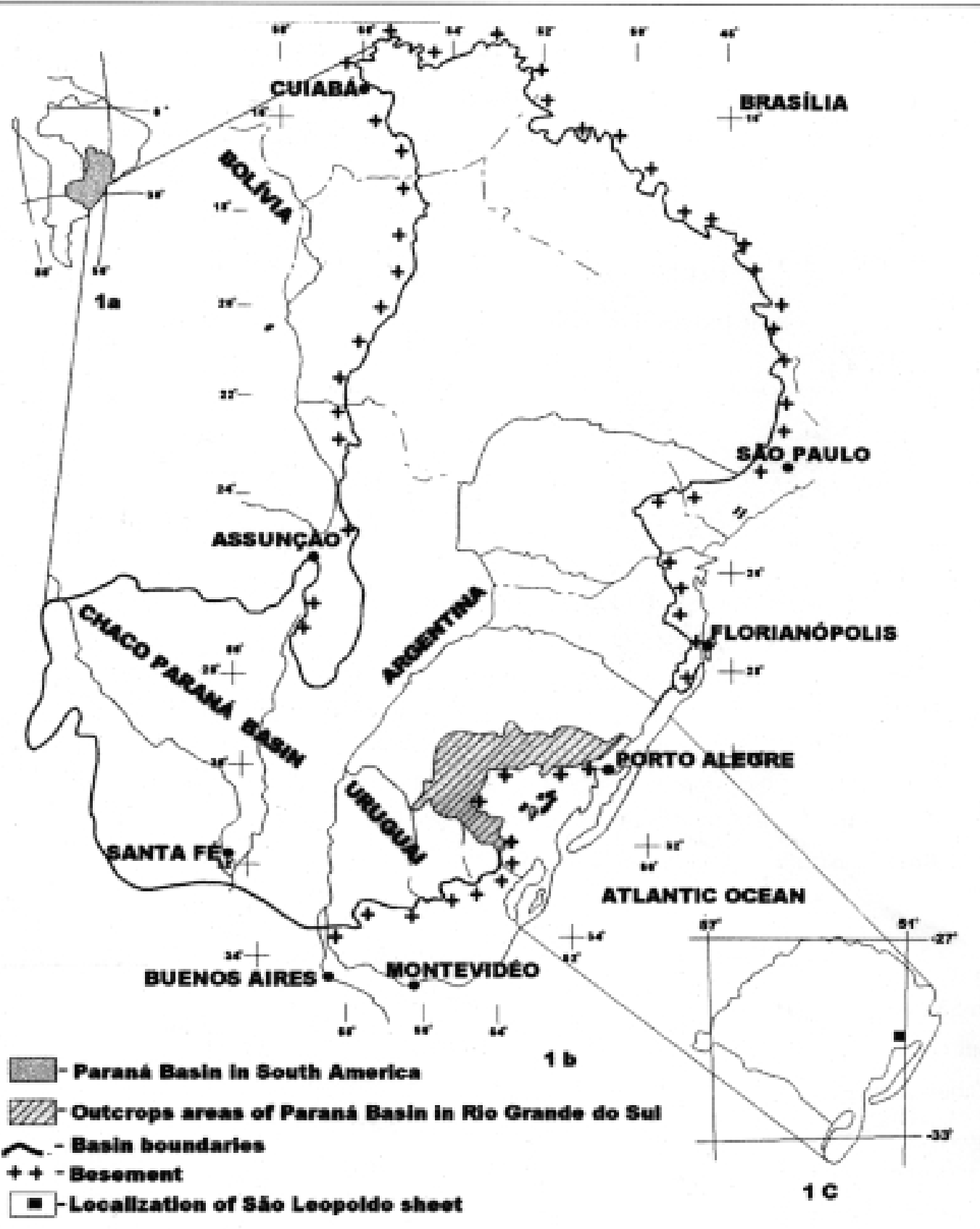

Fig. 1 - a. Position of the Paraná Basin in South America; b. Area occupied by the Paraná Basin in Brazil, Argentina, Uruguay and Paraguay; c. Localization of the studied area in the State of Rio Grande do Sul (according to Zalán et al. 1987, modified). 


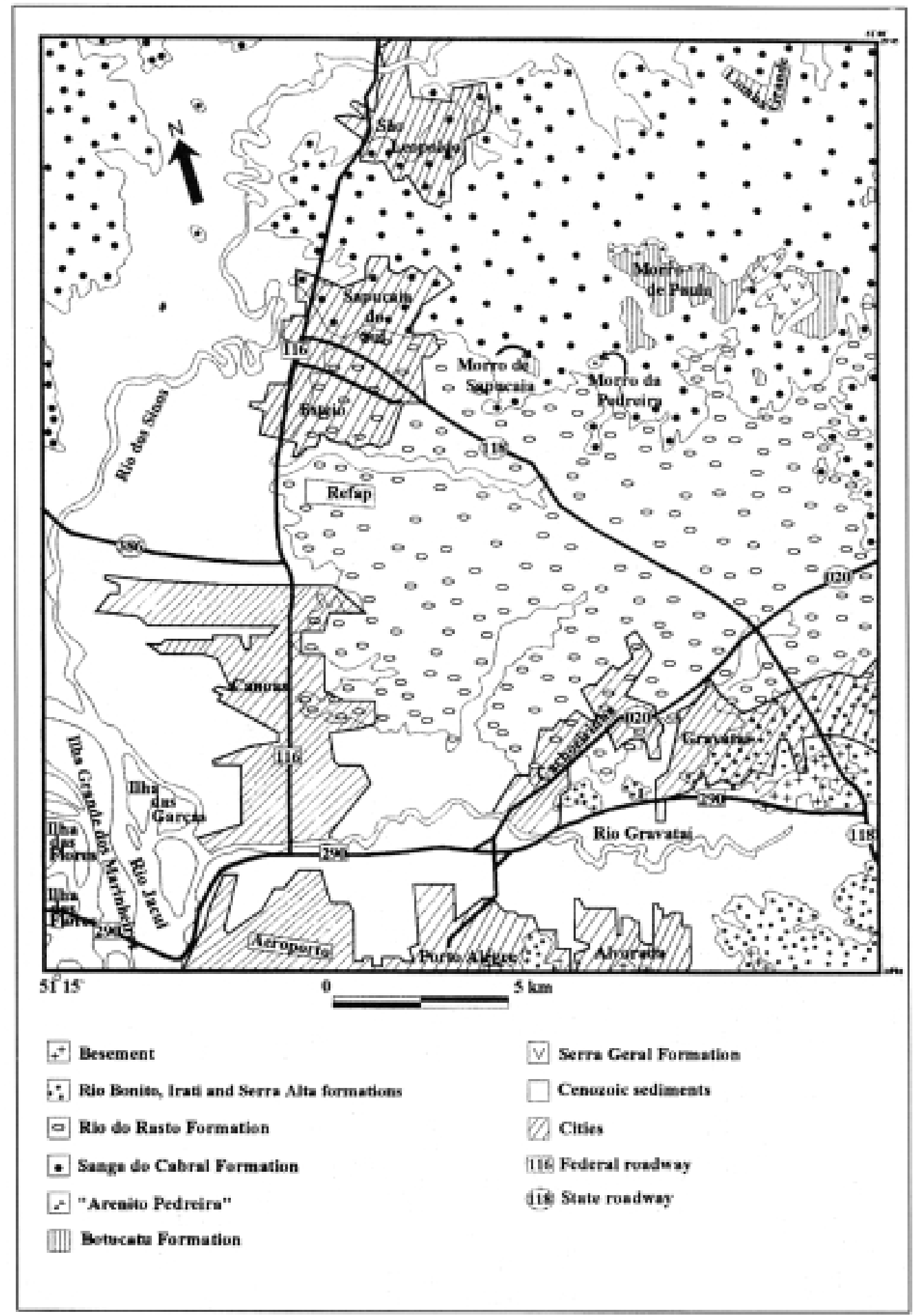

Fig. 2 - Simplified geological map of the area of São Leopoldo, State of Rio Grande do Sul, showing the places of exposure of the Pedreira Sandstone (Morro da Pedreira, Sapucaia do Sul and Morro de Paula, São Leopoldo). 
Caetano-Chang \& Tai (1998) described conglomerate sandstones, informally named as Itirapina Conglomerate Sandstones, located between the Pirambóia and Botucatu formations, in the state of São Paulo.

According to several authors, the Sanga do Cabral formation, overlaid with the mentioned sandstones, is at least partly relatable to $\mathrm{Pi}$ rambóia Formation (Gamermann 1973, Soares 1975, Faccini 1989, Lavina 1991, Lavina et al. 1993, Nowatzki 1997).

\section{FACIES DISTRIBUTION}

The Sanga do Cabral formation, in São Leopoldo area, is composed by fine to very finegrained, quartz-feldspathic, friable, reddish sandstones, with medium to large-scale crossstratifications (according to Ashley 1990, adapted), of eolian origin (Figure 3a), in the top. The intermediate portion is made up of medium to coarse-grained sandstones, with small-scale cross-stratifications, of fluvial origin. The base is composed by breccias with gradative inverse structures, probably deposits of alluvial fans.

Overlaying that, there are 20 meters of sandstones, discontinuous, generated in an eolian environment where dune deposits are interposed with thick packs of wet interdunes (Figure $3 b$ ). The name Pedreira Sandstone is informally proposed for this succession, after its better outcrop in the Pedreira Hill, in Sapucaia do Sul, a neighbor city to São Leopoldo.

Though there are mudstones repeatedly interposed to the sandstones in the wet interdune facies they are percentually unexpressive $(\sim$ $5 \%$ ). The sandstones make up about $95 \%$ of the total deposits. Most of the sandstones are red- dish, but there are also some yellowish, brownish and whitish.

The eolian dunes have a texture made up of thin to very thin quartziferous sandstones, though some feldspathic sandstones, one to two meters thick, may occur.

The thin to very thin grained sandstone layers, sometimes medium and coarse grained five to ten centimeters thick of the wet interdunes, are also made up of quartz, and more rarely, of feldspar. There are also tiny plates of muscovite, fine to very fine in size, which differ from the underlaid unit Sanga do Cabral formation. Interposed to the sandstones there are thin layers of mudstones 0.2 to $1 \mathrm{~mm}$ thick (Figure 3c).

The Pedreira Sandstone has a mineralogical composition of mono and polycrystalline quartz (95\%) and totally kaolinized feldspar (1\%). Lithoclasts of argillite, quartzite, fine grained sandstones and igneous rocks can also be found, as well as accessories of muscovite, epidote, allanite, apatite and pyroxenes (?).

While the eolian dune deposits show medium and large-scale cross-stratifications, grain flows, grain falls and translatent crosslaminations, the interdune deposits show, when not massive, beyond the translatent crosslaminations, several mudcracks in the very thin mudstone layers, which are filled up by the sand of the following layer. Ichnofossils (Figure 4a) and salt impressions may be related to the mudcracks (Figure 3d) (De Ros et al. 1998). Among these, Nowatzki et al. (1996) they also show features resembling vegetable remains (Figure 4b).

This pack is clearly from a continental and 


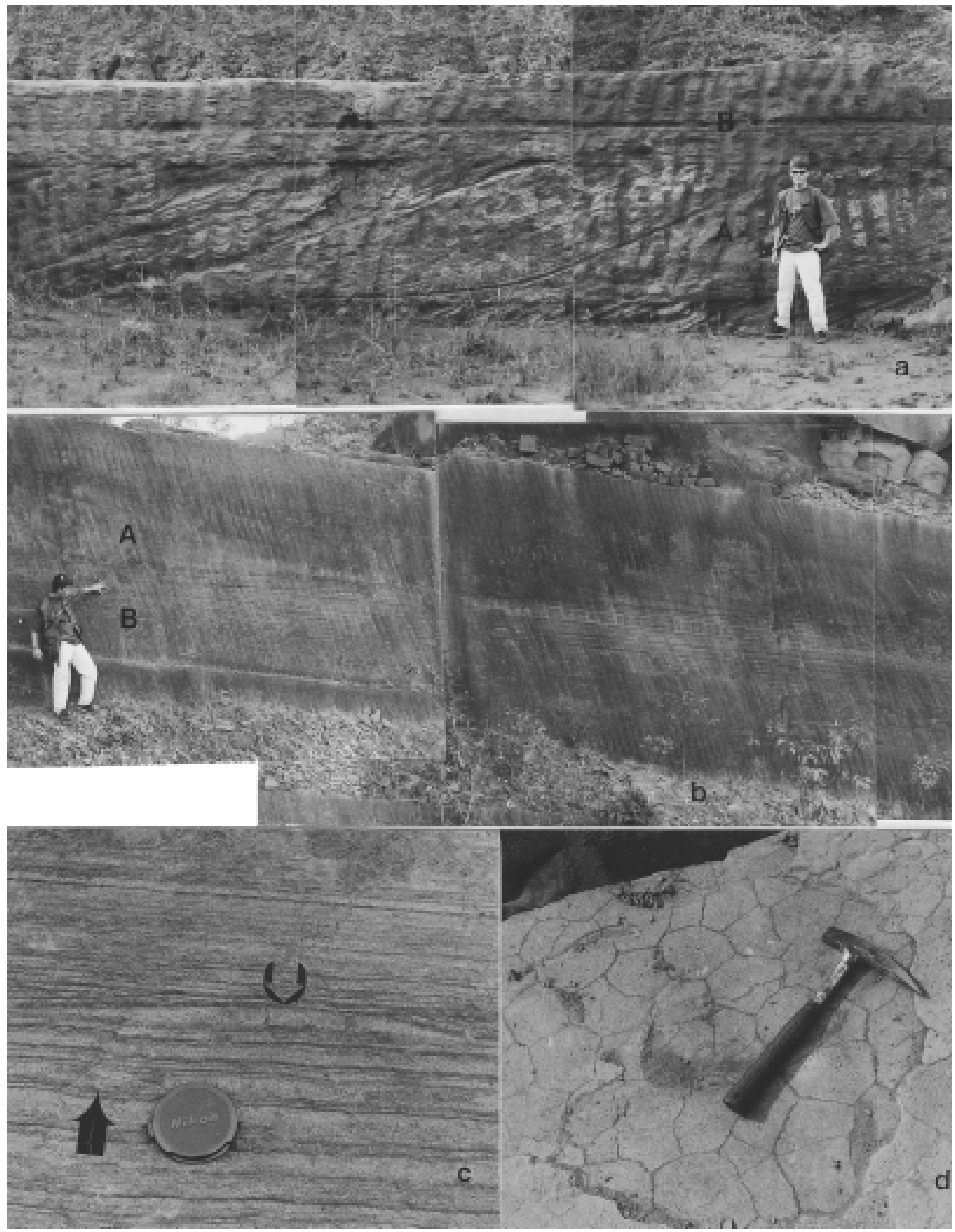

Fig. 3 - a. Upper Portion of Sanga do Cabral Formation, pointing out facies of eolian dunes (A) and dry interdunes (B); b. Eolianities of the informal unit Pedreira Sandstone showing eolian deposits (A) and wet interdune deposits (B); c. Sandstone layers interposed to mudstone in the wet interdunes of Pedreira Sandstone. The dark arrow points to the translatent cross-lamination and the light arrow to the grain flow that hit the interdune; d. Mudcrack casts in the wet interdune deposits of Pedreira Sandstone. 

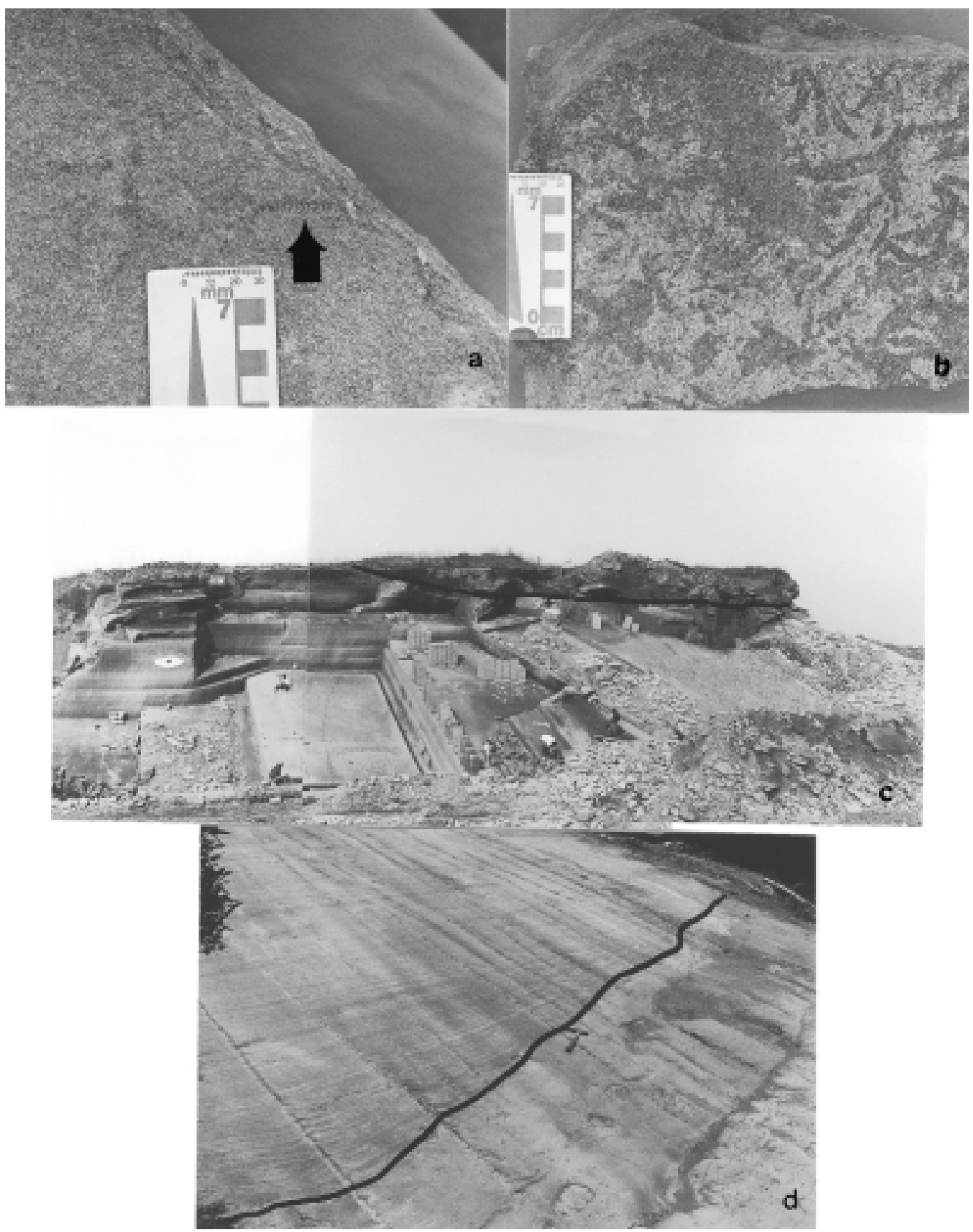

Fig. 4 - a. Taenidium (?) in wet interdune deposits of Pedreira Sandstone; b. Pavement covered of salt impressions and features resembling plant impressions still articulated (Pedreira Sandstone); c. Contact between the Botucatu Formation (upper part, above the nankeen trace) and the inclined layers of the Pedreira Sandstone (lower part). The mudcracks, ichnofossils and the impressions of salt or of plant remains are in these layers; d. Erosive contact (?) between the fine to very fine grained, quartz-feldspathic eolian dunes of Sanga do Cabral Formation (lower part, under the nankeen trace) and the Pedreira Sandstone (upper part), made up of medium to coarse grained quartziferous sand. 
desertic environment, like Sanga do Cabral and Botucatu formations. However, in the Pedreira Sandstone some points are striking. These are (1) the coarser grain size and the exclusive presence of eolian deposits, when compared to the underlaid Sanga do Cabral formation; (2) the difference of mineralogical composition from Sanga do Cabral and Botucatu formations, with which it is interposed; (3) the ichnofossil register; (4) the presence of wet interdune deposits with mudcracks; (5) the impressions of salt and possible vegetables. Of these characteristics, the last three have never been detected in Botucatu formation in the State of Rio Grande do Sul, as the last two which have never been mentioned for the Sanga do Cabral Formation, in this state.

The paleocurrents system is different in those units. While the eolian paleocurrents in the Sanga do Cabral Formation indicate that the winds migrated to southwest (big average $=$ $254^{\circ}$ ), the ones in the Pedrera Sandstone show that they moved to northwest (big average = $280^{\circ}$ ) and the ones in the Botucatu Formation had northeast direction (big average $=38^{\circ}$ ).

Although most of the Pedreira Sandstone is made of interdune deposits, where several layers with mudcracks occur, which indicates a practically horizontal sedimentation, a significant portion of the sandstones presents a dive between $15^{\circ}$ and $18^{\circ}$, what could indicate tectonic movement after the deposition (Figure 4c).

The ichnofossils show a great variety of shape and size. Its arrangement can be horizontal, perpendicular or diagonal to the deposition, while the lengths and diameters range from few millimeters to even some centimeters.

The presence of plant fossils (Nowatzki et al. 1996), however, is still a problem. There is a possibility that some or all of the features resembling vegetables were originated from the crystallization of salts (specially gypsita), which is very common in desertic regions (Dana \& Hurlbert Jr 1978, Dud'a Jr \& Ryjl 1991).

According to Kocurek \& Havholm (1994), the association of inorganic and organic features is a characteristic of desertic systems with wet interdunes, where the superior part of the ground water is exposed in the surface or close to it.

Even in today deserts an occurrence of wet periods can be registered. During these periods there are interruptions in the dune sedimentation, a growing in the area occupied by plants and an explosion of animal life, specially insects and arthropods (Talbot 1985).

\section{CONTACT RELATIONSHIPS}

Considering that only in two places of the São Leopoldo area the succession of the studied units can be observed, it is difficult to establish the contact relationship between them. Only observations made in other regions could help to clear up these questions.

Regarding the lower contact, there are three accepted possibilities: (1) the Pedreira Sandstone would be only the upper part of the Sanga do Cabral Formation, sedimented during a wet period in the desert, with more competent winds; (2) they would be two different units with conforming contact and (3) there would be a disconformity between Sanga do Cabral Formation and the Pedreira Sandstone, as shown 
by the abrupt, possibly erosive appearance of medium to coarse grained quartziferous sands from the informal unit, with the registration of different paleocurrents, over the quartzfeldspathic, fine to very fine grained, friable sands of the underlaid formation (Figure 4d).

The upper contact between the Pedreira Sandstone and the Botucatu Formation is probably disconformable. Conforming that, there are the differences in the mineralogical compositions, in the sedimentary structures and in the paleocurrents, and the mentioned dive of the Pedreira Sandstone dive.

\section{CONCLUSIONS}

The depositional analysis of the Sanga do Cabral Formation suggests an increase in the region aridity, in the direction of the top of the unit, which is interrupted by the registers of the wet interdune deposits of the Pedreira Sandstone.

During the Pedreira Sandstone deposition, the water in the region would be supplied by the ascension of the groundwater level and, maybe, by increasing air humidity. The sedimentary structures (mudcracks, ichnofossils, salt impressions - and occasionally plants) suggest an inflow of water that, though not much significant, was enough to transform the area into a humid desert.

The coarser grains of this unit's sandstones, compared to those of the eolian Sanga do Cabral Formation, underlaid, show an increase in the winds strength or in the disponibility of coarser sand, which may have been caused by topographical renewal of the region. This would be compatible to the occurrence of major tec- tonic events in the south portion of South America, according to some authors (eg. Zalán et al. 1987); that would explain the existence of possible tectonic movements prior to the rifting of the south part of the Paraná Basin, thus fixing the beginning of the sedimentation of the Botucatu Formation.

During the deposition of the eolian dunes of the Botucatu Formation the water was no longer present, at least in its upper portion. As a consequence, the climate must have been extremely hot and dry, thus making the life of the animals responsible for the ichnofossils, difficult or impossible. That's why registrations of sedimentary structures mentioned earlier (mudcracks, ichnofossils and impressions of salt and "plants") have not yet been found in this region.

\section{ACKNOWLEDGEMENTS}

We thank Universidade do Vale do Rio dos Sinos - UNISINOS for the logistic support.

We are also grateful to José L. Lindenmayer and Marcelo Granjeiro, students of the Geology Graduation Course and the M.Sc. Carla Klein and Victor L.S. Bocalon, for their help with the field tasks.

Finally, our special thanks to the Drs. Tânia Lindner Dutra and Renata Guimarães Netto, for the critical review of this paper.

\section{REFERENCES}

ANDREIS RR, LAVINA EL \& PAIM SG. 1984. Geologia da Folha de São Leopoldo-RS. In: BARBERENA MC (coord.) Mapeamento Geológico, Estratigrafia, Recursos Minerais e Paleontologia do Permiano Superior e Triássico Médio do Rio Grande do Sul. Convênio FINEP-UFRGS 
$\mathrm{n}^{\circ}$ 33.82.0.324.00-Geociências, sub-projeto V. Relatório final. Mapa $n^{\circ}$ 9, escala 1:100.000. v.2. P. 35-42.

Ashley GM. 1990. Classification of large-scale subaqueous bedforms: a new look at an old problem. J Sed Petr 60: 160-172.

Caetano-Chang MR \& Tai WF. 1998. Aspectos sedimentológicos e estratigráficos dos arenitos conglomeráticos da passagem entre as formações Pirambóia e Botucatu (MesozóicoBacia do Paraná), no Estado de São Paulo. In: Congreso Uruguayo de Geologia, 2, Punta del Este. Actas... Punta del Este, p. 21-23.

DANA JD \& Hurlbert JR CS. 1978. Manual de Mineralogia. Reimpressão. Rio de Janeiro. Livros Técnicos e Científicos Editora S.A. 643p.

De Ros LF, Guerra-Sommer M \& Tomazelli LJ. 1998. Moldes de cristais de gipsita como pseudofósseis no Arenito Botucatu, RS. Pesquisas, em impressão.

DuD’A JR R \& RyJL L. 1991. La Gran Enciclopedia de los Minerales. 2a. ed. Praga. 520p.

Faccini UF. 1989. O Permo-Triássico do Rio Grande do Sul. Uma análise sob o ponto de vista das Seqüências Deposicionais. Porto Alegre. 133p. (Dissertação de mestrado. PGGUFRGS).

FACCINI UF \& NowatzKi CH. 1993. A borda sudeste da Bacia do Paraná (RS-Uruguai). In: Seminário-Feira de Pesquisa e Pós-Graduação, São Leopoldo, 1. 1993. Resumos... São Leopoldo, UNISINOS, 1, P.142.

Fensterseifer HC. 1979. Contribuição à Estratigrafia da região de Gravataí, Rio Grande do Sul, Brasil. Porto Alegre. 182p. (Dissertação de mestrado. PGG-UFRGS).

Gamermann N. 1973. Formação Rosário do Sul.
Pesquisas, 2: 5-35.

Kocurek G \& Havholm KG. 1994. Eolian sequence stratigraphy - A conceptual framework. In: Weimer P \& Posamentier HW (eds.). Siliciclastic Sequence Stratigraphy. AAPG. Mem 58: p. 339-409.

Lavina EL. 1991. Geologia sedimentar e paleogeografia do Neo-permiano e Eotriássico (intervalo Kazaniano-Scythiano) da Bacia do Paraná. Porto Alegre. 2v. 675p. (Tese de doutorado. PGG-UFRGS).

Lavina ELC, Faccini UF \& Ribeiro HJS. 1993. A Formação Pirambóia (Permo-Triássico) no Estado do Rio Grande do Sul. Acta Geol Leopol 16: $279-1979$.

MorRIs RH. 1963. Geologia geral das quadrículas de Gravataí, Taquara e Rolante - Rio Grande do Sul. Porto Alegre, Esc. Geol. P. Alegre. Publ Esp no. 5. $37 \mathrm{p}+3$ mapas.

NowATZKI CH. 1997. Revisão estratigráfica da Bacia do Paraná, intervalo abrangido entre as aloformações Rio do Rasto e Botucatu, Folha de São Leopoldo, RS, Brasil. São Leopoldo. 246p. (Dissertação de mestrado. PGG-UNISINOS).

NowatzKi CH, Dutra TL \& Klein C. 1996. Impressões de vegetais em depósitos de interdunas da Formação Sanga do Cabral (Permiano Superior-Triássico Inferior), RS. Acta Geol Leopol 19: 25-42.

SoARes PC. 1975. Divisão estratigráfica do Mesozóico no Estado de São Paulo. Rev Bras Geoc 5: 229-251.

TALвот MR. 1985. Major bounding surfaces in aeolian sandstones - a climatic model. Sediment 32: 257-265.

White IC. 1908. Relatório sobre as "Coal Measures" e as rochas associadas ao sul do Brasil. 
In: Simpósio do Gondwana, 7. São Paulo, 1988. Edição Fac-Similar do Relatório Final. Parte I. São Paulo, SP. DNPM. P. 1-300.

Zalán PV, WolfF S, Conceição JCJ, Astolfi MAM, VIEIRA IS, APII VT \& ZANotTo OA. 1987. Tectônica e sedimentação da Bacia do Paraná. In: Simpósio Sul-brasileiro de Geologia, 3. Curitiba. Atas... 1: 441-447.
Zeltzer F, Paula CC \& Nowatzki CH. 1992. Mapa geológico da Folha de São Leopoldo RS. Escala 1:50.000. Acta Geol Leopol, Série Mapas, 1: 3-14. 